\title{
Development Discourse of Minor Tank Villages in Sri Lanka: A Case Study of Three Minor Tank Villages in Anuradhapura District
}

\author{
Dr. MM Jayawardena \\ Senior Lecturer in Economics, Department of Social Sciences, Faculty of Management, Social Sciences and Humanities, Kotelawala \\ Defence University, Sri Lanka
}

\begin{abstract}
Minor tank villages in Sri Lanka have historically survived as agricultural villages. Yet, today, these villages remain as inherently poverty trodden rural settlements despite different policy efforts of development. Addressing the Marxian analysis of under development, this study critically analyses the present conditions and the interpretation of development of these villages. The research questions of the study are: On what basis can development of these villages be assessed? In which direction are the infrastructure and the institutional environment of these villages heading? What are the issues of development discourse in minor tank villages? What are the factors that have influenced the situation of these villages? What is the most appropriate development model for these villages? The study is inductive and the multiple research method is used for both information gathering and in analyzing the problem. Using the purposive and stratified sampling methods the villages of Mahakumbukgollewa, Gonewa and Thalattewa in the Anuradhapura district were selected for the study. Surveys, participatory observations, focus group discussions and in-depth studies were the main types of investigations. The participants for the focus group discussions were selected under snowball sampling method. Further, randomly selected fifty families from each of the three villages were investigated by using a pre-tested questionnaire to assess the present livelihood of the minor tank village community. Based on macro and micro level information of the sample villages, a cohort analysis and a historiographical analysis were done. The study found that the village community has been further marginalized and intertwined with new socioeconomic hazards despite physical and socio-economic changes. The literature of the subject reveals that many of the development models including the concept of sustainable development are theoretically as well as empirically alienated because as there is no constructive base that is compatible with the contextual configurations of the community. Analyzing the contextual configurations of minor tank villages and their heritage, an economic model leading to spiritual development is identified. This model is incorporated a theoretical base by linking the spiritual path of Buddhism predominant in the community with the concept of collectiveness described in Marxism. Here, ontological and epistemological factors are addressed in filtering the life philosophy at individual and community level. The new model is applicable against marginalization and the challenges of development at the levels of individuals, family, village, the cascade of tank villages and the community. Empirical studies are recommended for testing of the model for verification.
\end{abstract}

Keywords: Minor tank villages, development discourse, spiritual development, life philosophy

\section{Introduction}

"Development" is a much argued concept in the contemporary world. The current dilemma of development has become an outcome of empirical experience of development processes of different societies in the contexts of inter and intra relationships at village, regional, national and international levels. This particular issue of development is more applicable for countries like Sri Lanka mainly because of the impact of "colonialism" and "imperialism" as argued by development economists as well as sociologists. The Marxian analysis and the neo Marxian analyses help in understanding the marginalization of certain communities over others. Yet, the Marxian conceptualization has not been able to find answers for the underdevelopment either at micro level or at macro level mainly because materialism alone is taken as a fundamental of human behaviour to describe the working class domination, under Marxism.

The concepts of development starting from economic growth indicators to PQLI and HDI followed by supplementary measures such as Happiness Index have not been able to give a justifiable explanation to the development discourse (Allen, 1991; Ranis, Frances, Aljendro, 2000). In this situation, analysis of development addressing the contextual features along with spiritual life needs to be integrated with development and thus development discourse needs to be strengthened while considering the ontological and epistemological bases of human behaviour leading to overall welfare of the human beings.

Minor tank villages are unique, historical and marginalized compared to other agricultural and non-agricultural settlements in Sri Lanka. These villages have also failed to restructure the settlements with substantial socio-economic and political infrastructure development, and therefore, the settlers have not gained desired outcomes as in the case of other settlements in Sri Lanka. However, there is a substantial amount of evidence that these villages had existed with prosperity under the feudal system in the past (Hector Kobbekaduwa Agrarian Research and Training Institute (HKARTI), 2004). In this background, this study is focused on social transformation of selected minor tank villages with an emphasis on the development issues to bridge the gaps in social science perspectives. The outcome of this study will enlighten the development discourse of marginalized rural communities in Sri Lanka and it will help in identifying a new economic model for the marginalized rural settlements in Sri Lanka as well as the marginalized nations under current globalization. 


\section{International Journal of Science and Research (IJSR) \\ ISSN (Online): 2319-7064}

Index Copernicus Value (2013): 6.14 | Impact Factor (2014): 5.611

\section{Research Problem}

The "Purana (old) Tank Villages" in the dry zone are the most significant types of villages that have been affected by the development dilemmas under modernization. During and after the colonial administrations under different programs of "development assistance" based on different concepts of modernization, the traditional systems in these villages have been structurally affected. However, how far such changes are sustainably beneficial to the communities of these villages and to the country at large are questionable. Many of the rural settlements based on minor tanks in Sri Lanka have been historically unique because of Sri Lanka ${ }^{e s}$ cultural and religious significance as an Asian country (Gunnar Myrdal 1898-1987). Therefore, the modernization of these settlements under liberalism and neo liberalism, has led to a conflict of interests at individual level as well as at village level. This has been further critical because of the policy confusions towards the development of these minor tank villages. Even though Marxism and Neo-Marxism have explained this scenario, no empirically effective solutions are available. Further, in spite of the fact that all the villagers are traditionally Buddhists and the Buddhist philosophy discusses how man can defeat the evils of life leading towards full enlightenment, the minor tank village communities in the current context are not benefitted much in their vulnerability as compared with the old village settings. Thus, the village communities of minor tank villages have not found solutions to their socio-economic problems neither from modernization no from the religion as in the past. Under these circumstances, there is a need to reinterpret development in line with a new development approach that matches with the existing conditions in the marginalized minor tank villages in Sri Lanka.

\section{Significance of the Study}

The symposium on "Small Tank Herritage and Current Problems" conducted by the HKARTI concluded that there are enough studies on technical aspects of minor tanks as well as minor tank villages conducted by researchers such as CR Panabokke, CM Madduma Bandara, PB Dharmasena etc., but no serious study of similar nature on the socio economic cohort of the minor tank villages. Therefore, socio-economic studies on marginalized rural settlements like minor tank villages are important

\section{Objectives of the Study}

1) Identify the evolving patterns of socio-economic and political infrastructure and institutional environment of minor tank villages.

2) Identify the theoretical background of development discourse of minor tank villages.

3) Identify the issues of development of marginalized rural settlements.

4) Identify an alternative approach of development for rural settlements.

\section{Research Questions}

The study was conducted by addressing the following research questions,

1) In which direction are the infrastructure and the institutional environment heading?

2) What is the level of development in minor tank villages?

3) What are the issues of development in minor tank villages?

4) What would be an appropriate development approach for rural settlements?

\section{Research Methodology}

In order to achieve the objectives of the study, a critical analysis of minor tank villages of Mahakumbukgollewa, Gonewa (Kallanchiya) and Thalattewa in Anuradhapura district was conducted with the focus on the existing literature on development as well as minor tank village development. The information gathered by the author for the study on "Development Feasibilities of the Villages under Minor Tanks in Sri Lanka" conducted in 1983/84 was taken as the base for this study. The historiographical information and both primary and secondary data on the present socioeconomic conditions of these villages were gathered to assess the historical process of development. Herein, investigations of official records of both formal and informal nature, secondary reports, publications and focus group discussions with the stake holders of minor tank village development programmes were used as the main sources of information for this study. In order to conduct focus group discussions, the farming community, senior citizens, religious leaders, NGOs, political authorities of the villages and government and non-government officials were selected under the snowball sampling method. Thus, the methods of data collection as well as the analysis are multiple in nature. In making final conclusions, both descriptive and prescriptive analytical methods were complementarily used.

In order to identify the evolving processes of socio-economic and political structures of minor tank villages during the thirty years after $1983 / 84$, a cohort analysis of the three selected "Purana" Tank Villages was done. Here each of the "Purana" Villages is taken as a collective organism in which an individual family member becomes a unit of this collective entity within the particular geopolitical setting. Micro level information gathered through the questionnaire survey was also used in a complementary manner in the critical evaluation of community behaviour as well as in the analysis of the production and consumption pattern of the community. Thereafter, addressing on the potential of development, resource availability, outcomes of development assistance programs, issues of development experience of the stake holders, and discourses of development of minor tank villages are streamlined. Finally, Likert scale information was analysed using SPSS to assess the present level of community satisfaction and to find the rationale of the proposed model of development. 


\section{International Journal of Science and Research (IJSR) \\ ISSN (Online): 2319-7064}

Index Copernicus Value (2013): 6.14 | Impact Factor (2014): 5.611

\section{Development Reference To Sri Lanka: Theoretical Background.}

The current development discourse is based on "European Enlightenment". The western development discourse identified the countries in the world as irrational and rational or as backward and modern in dealing with development issues. Under this classification, Asia, Africa and Latin America are irrational or backward societies (Hastrup: 65, 1995). According to the western view Asia, Africa and Latin America are more or less irrational backward societies and thus struggling for development.

According to historical information, in the communities of the Indian subcontinent where spiritual development is emphasized as an important feature in the society, there has been a tendency towards more vulnerability in the process of social transformation. The impact of this vulnerability has become critical in the marginalized countries and regions more than in others. The colonial rulers during their tenures have used strategic approaches according to their own calculation for easy management and thus the smooth transformation of these societies in the natural flow has been affected (Sen, pp.1-25, 1997). This kind of strategic administrative manipulation was prominent in the early period of colonization and became less in the latter stage. However, the impact of such strategic approaches keeps on spreading into future generations as well. Under these circumstances, communities of the colonized countries of the Indian subcontinent were either distorted in their behaviour or became alienated in the society. Both types of behaviour have affected the smooth transformation of the society (Jayawardena, 2008).

In the post-colonial era these states were totally dependent on the government. This particular government dominancy (governmentalization) in the developing world, linked with globalization and new imperialism (Foucault, 1979). Under these circumstances, there is no significant role to be played by the economic, political and cultural systems that would have otherwise minimized the harmful effects of authoritarian control, thereby making socio-economic relations consistent with the "natural transformation" of societies like in Europe (Jayawardena, 2013). Therefore, the concepts of modernization as well as the western interpretation of economic growth and development need to be revisited.

The concepts of economic growth and development which emerged within the western society are compatible with the western mode than with the eastern where the accumulated contextual features are different. In the contemporary interpretation of development in the countries such as Sri Lanka "natural transformation" was not taken into consideration like in Europe (Geertz, 1983, Brow James, 1995). Here "natural transformation" refers to an atmosphere in which changes are determined with the dynamism of "check and balances" of the respective society depending on social pressure (Jayawardena, 2013).
Furthermore, economic growth and development in the early stage were considered as the same and believed to be endogenous that depended on labour productivity (Adam Smith, 1776). According to Adam smith, an individual is self-interested and plays a dominant role in the determination of production. Later in the 1930s, the depression in Europe was not been able explained by the classical concepts of economics. As a consequence the neo-classical concepts of economic growth and development were recognized and it was believed that the government regulatory body could increase production. As a consequence, the government sector that was aligned with neo-liberal economic thoughts became prominent replacing the endogenous growth with exogenous growth. The impacts of such changes have created problems for developing countries like Sri Lanka despite the short run advantages (Long, 1988).

After the $2^{\text {nd }}$ World War the concepts of economic growth and development were redefined and prescribed with different formula. Accordingly economic growth was identified as "continuous increase in real national production" whereas economic development was identified as "improvement in the general welfare of the public" which was indexed as Physical quality of life Index (PQLI) in the early stage of post war period and thereafter as Human Development Index (HDI). All the prescriptions and interpretations of economic growth and development were based relative to the western societies (Rostow, 1960).

The theories of economic development in the contemporary world have been constructed on two schools of thoughts of the western society. The concepts of modernization which is focussed on present to future, describes the progress of an economy under different approaces. Rostow's five stages of economic development (1960), Arthur Lewis structural change model (1954), Harrod-Dorma economic growth model, Robert Solow"s economic growth model (1957) and Romer Model (1986) are the major contributors of Modernization theory. All these theories explain how the developed countries have come to the present stage of development and the current position and signal for the developing world (Todro, 2013). Under this interpretation the marginalized countries had to undergo further difficulties as the new indexes have not given attention to the contextual features of those countries different from the west, and as a result these countries were forced to adjust their societies through various reforms to suit the requirements of the western countries" prescriptions that have not been addressed on the identical features of these countries appropriately.

Apart from the western modernization theories of development, there are other development theories that are based on Marxian analysis. According to the Marxian school of development discourse, the under development is an outcome of capitalist class hegemony that dominate the production relationships of these societies. The „Centre Periphery" relationship is taken as the focal point of these analyses. Among them „Dependency Theorye is popularly known. All these explanations of economic development have concentrated on challenges and path finding approaches of development (Gardner and Lewis, 1996, Amin, 1990). Yet, because of the inconsistencies of the dependency models and the socio-economic and political vulnerability due to external 


\section{International Journal of Science and Research (IJSR) \\ ISSN (Online): 2319-7064 \\ Index Copernicus Value (2013): 6.14 | Impact Factor (2014): 5.611}

interventions, there has been no significant validity of such explanations. Therefore, the social transformation theories of Karl Marx (1818-1883), Durkheim (1864-1920), and Ferdinand Tonnies (1855-1936) followed by Gramsci (18911937), Althusser (1998), Baran (1957),Amin (1990) etc. were under discussion in the contemporary literature, need to be considered with extra care before reaching conclusions (Geertz, 1983).

In the contemporary era along with the influence of neoliberalism followed by the concept of globalized development that were ushered and monitored by the prescription of world organizations such as IMF, World Bank and their allies encourage developing countries to follow the market system which they consider as medicine for all types of hindrances of development. The "Structural Adjustments", "Expert Knowledge", World Trade Organization (WTO), etc. for economic development followed by "Washington consensus" have become widely known development phenomena in contemporary discussions.

Under these circumstances many of the developing countries have been facing serious repercussions of the conflict of development approaches that have led to socio-economic and political chaos engineered by socio-economic and political interests of hegemonic parties at national level and international level. This is more applicable to marginalized countries like Sri Lanka than to others. The concept of "sustainable development" is under discussion as an alternative for global challenges of development. Yet, sustainable development remains as an ideological concept as it has failed in its empirical perspective as far as developed and developing countries are concerned. Therefore, there is a gap in the development discourse in the context of many of the developing countries like Sri Lanka. Under these conditions development economists search for a new development discourse towards the marginalized countries of the world such as Sri Lanka, which are struggling for their development mainly because of the ignorance of identical features of individual countries and regions. The concepts of Gross Human Happiness (GHH) and Gross National Happiness (GNH) that address identical features of individual economies aligned with individual and total welfare of the society, signal for alternative development discourse against the current issues and the problems of the developing world (http://www.sustainablescale.org). This kind of new approach is important for marginalized countries because many of these countries struggle with political economy related factors that are inter-linked with the so called development and the countries of world economic hegemony. The same development discourse is applicable in describing regional underdevelopment as well as under development within a country like in minor tank villages. (Althussar, 1996).

\section{Minor Tank Villages in Sri Lanka}

The minor tank villages are officially with command areas of approximately $80 \mathrm{Ha}$ (200 Acres). According to the government regulations this category of irrigation comes under the Department of Agrarian Services (DAS). The minor tank technology in Sri Lanka dates back to preAnuradhapura period ( $5^{\text {th }}$ century BC). However, it is true that during the Anuradhapura period the minor irrigation systems were widely observed with an improvement in technology. The number of minor tanks available in Sri Lanka is over 25,000 (Jayawardena, 1988; Economic Review, 1982). However, functioning minor tanks are approximately 12,000 (Jayasena et al, 2011). Out of them about 68 percent of tanks are in the Anuradhapura and Kurunegala. Under typical dry zone characteristics, in Anuradhapura alone there are over 3900 (approximately 30 percent of total minor tanks in Sri Lanka) (Gazette Extraordinary Notification 1704/6/2011 May $2^{\text {nd }}$ ).

The Anuradhapura district is important firstly because of its historical significance. Secondly, because of the heavy dry zone features and finally because of the unique features of minor tank villages that link with ancient civilization. Most of the minor tank villages as well as the livelihood of the respective community in Anuradhapura are totally dependent on the amount of water in the tank (Out of 33 Agrarian Service Centre areas, 15 are not fed with either Mahaweli or any other major irrigation system). The minor tanks which are not fed by the major irrigation schemes are extremely marginalized as far as the economic prosperity is concerned. The amount of water in the tank is totally determined by the rainfall of the respective season. Generally the minor tank villages get substantial rain fall to fill the tank to its full capacity and can cultivate all the paddy land only during the Maha season (Sep-Feb). In the Yala season (March-Sep) these settlements receive less rain and therefore, generally tanks are not filled to their fully capacities and thus there is no guarantee of cultivation of paddy during the Yala. In the traditional system, if villages get less rain the villagers save the tank water for other purposes of the village and engage in chena cultivation for survival. Under the traditional system farmers had been practicing bethma and kekulama cultural patterns under, extreme drought conditions even in the Maha season (Darmasena, 2004). Therefore, the minor tank village communities had been used to surviving under drought conditions throughout history

Villagers of many minor tank settlements are Buddhists and their livelihood has been cultured with Buddhist thoughts. This ancient system of settlements was identified with the concept of „Wewai, Dgabai, Gamai, Pansalai'. Later it was interpreted as „Hydraulic Civilization (Leach, 1959, 1976). The concept behind the „Hydraulic Civilization" was to "use the rainfall to the maximum". The cascade system of irrigation was identified in the process of adjustment to the restrictions of climatology, topography and other nature related factors. This traditional system has been ecologically harmonious, nature friendly and flexible to climatic and ecological changes (Madduma Bandara, 1982, 1985, 1995, Panabokke, 2000). This has been challenged under a new development paradigm, thus the traditional livelihood system of these marginalized villages has been badly affected. However, United Nations is with the view that this traditional knowledge is more compatible with the ground conditions and also dynamic in nature, thus it is said that the traditional system of management had less problems in the utilization of resources under a restricted environment.

"Traditional knowledge consists of practical and normative knowledge concerning the ecological, socio-economic and

\section{Volume 4 Issue 12, December 2015}




\section{International Journal of Science and Research (IJSR) \\ ISSN (Online): 2319-7064}

Index Copernicus Value (2013): 6.14 | Impact Factor (2014): 5.611

cultural environment. Traditional knowledge originates from people and is transmitted by recognizable and experienced actors. It is systematic, experimental and handed down from generation to generation and culturally enhanced. Such a knowledge supports diversity and enhances and reproduces local resources" (UNCCD)

Contrasting to the above stance, modernization identifies these communities as poverty trodden and introduces different projects to help them. For example, „National Freedom from Hunger Campaign "e was established in 1962 as a NGO to help these villages. Under modernization, in the name of development, rural economies have been either subjected to commodification and capitalization followed by cooperation/integration to national and international economy (Long, 1988). The political economy related factors have accelerated such commodification and capitalization by providing complementary conditions through institutional arrangements (Beck, et al. 2001). The minor tank villages that are unique as rural settlements have been gradually trapped in a dichotomy between the modernization and traditional systems and these communities have become vulnerable in their socio-economic life because of the political economy back alienated programs and projects that have not considered the contextual features of minor tank villages.

Paddy farming, the major crop in the traditional agricultural setting has been later changed to cash crop dominated agriculture along with the influence of the "Green Revolution", followed by market liberalization (Gunasinghe, 1996). Subsequently, the impact of political economy on the village community has made a chain of structural changes in the production as well as in the livelihood of the agricultural communities in Sri Lanka. Yet, the marginalized rural agricultural communities in the minor tank villages are comparatively isolated and therefore their relationship with main stream communities of the rest of the country is rather limited, despite the so called openness and market liberalization prescribed by modernization. Under these conditions, the minor tank villages are with high resistance to modernization, firstly because of the historical and traditional environment in which the farmers are born, and then because of the biological and socio-economic constraints of agriculture in these areas (Jayawardena, 1988). In this situation, these minor tank villages have been rapidly thrown into the vulnerable conditions under modernization that links with the political economy extended to different layers of hierarchy from village to international level. This hierarchy includes a chain of leaders who dominate the decision making process with respect to the socio-economic and political process at different levels.

There is a chain of political economy cycles intertwined with the economy at different levels making an impact on the village and its relationships. At village level the bourgeoisie either potential or existing is linked with the regional or provincial level of such bourgeoisie and followed by the national level capitalist class. Unlike in the past each bourgeoisie and the capitalist class are closely associated with political leaders as both parties are mutually benefitted in achieving their objectives. The final stage of such relationships is extended to inter and intra national business world linked with regional and international hegemony. Therefore, the current high consumerism, the technology and the mode of production in the villages are unable to be controlled by the community by themselves unless they make a structural change in the existing system. Therefore, the context of economic growth and development of these villages need to be reinterpreted in line with human welfare based on spiritual development guided by Buddhism and on collectiveness guided by Marxism; firstly because saturation of satisfaction is the human endeavour in the end, secondly these marginalized villages have less opportunities and they cannot cope up with unlimited consumption, thirdly, these kinds of rural settlements, also can play a significant role within the larger society by exploiting the unique features of rural settlements and finally, maintaining such conditions sustainably with a direction towards the optimum level, both as individuals and as a community. Such change is matched with the theory of factor endorsement and trade and would be compatible even with the rest of the societies or countries in their competitive development endeavours (Keneth et.al, 2000).

In the sample villages, it was observed that the village level political leaders who work either formally or informally as the helping hand of political leaders at provincial level or national level are the key elements in the social hierarchy. This chain of activities is extended up to the international level under the current globalization (Paul A. Baran, 19091964).

Introduction of Agro Wells which is an outcome of modernization followed by commodification and capitalization from which the farming community was motivated for growing cash crops has been trapped in the system especially as far as the concept of sustainable development is concerned. The construction of Agro Wells is a costly project for the villagers and therefore only those who are comparatively better off could spend money for this purpose. However, the tendency of construction of Agro Wells has created the conditions for hierarchical development of political economy relationships in the minor tank villages (Beck, et al. 2001, Jayawardena, 1988). Further, due to hydrological restrictions in the minor tank villages where there are water table restrictions, the ground water needs to be managed carefully (Dharmasena, 2004) Therefore, the Agro Wells as a project for acceleration of economic growth, cannot be considered as a sustainable solution for minor tank villages as it can create unforeseen problems for the people especially in the long run.

Buddhism which was the traditional overall guiding mechanism of this farming community also has not been able to provide a relief for their vulnerability in the present day context unlike in the past. The western culture forced on the local community under different paradigms has confused the society as well as the religious leaders in the local community. Yet when one considers the philosophy of Buddhism, there is a possibility of providing a strong base at community level as well as at individual level, if the necessary conditions are available for them to understand the Buddhist philosophy while focussing on the challenges of these settlements. 


\section{International Journal of Science and Research (IJSR) \\ ISSN (Online): 2319-7064 \\ Index Copernicus Value (2013): 6.14 | Impact Factor (2014): 5.611}

The Marxian and Neo-Marxian analyses also help to understand the economic and social vulnerability of the livelihood perspective of the community in spite of the fact that the empirical evidences witness that this marginalized community has not been benefited from the working class domination presented in Marxism (see section 7).

Under these circumstances, there is a need to comprehend the existing socio-economic conditions while addressing the transformation of these villages to identify a suitable model that could sustain development of these unique villages.

The theoretical background and the empirical information of minor tank villages suggest that complementary use of Marxian and Neo-Marxian analyses referred to working class domination that is satisfied with the compatible level of production and consumption for the community to live and a livelihood directed by Buddhism that teaches how an individual can enlighten life through the wisdom of the four noble truth ( Dukkha sacca, Samudhaya Sacca, Nirodha Sacca and Marga Sacca (the Nobal Eight fold Path), Ven. Rahula,1959) would help in finding a sustainable solution to the problem of vulnerability of the minor tank village community.

\section{Development Cohorts of the Sample Villages}

The information gathered during the field visits reveals that the community and the villages have changed during the period of the last thirty years (1984-2014). Among the changes socio-economic, environmental, health, infrastructure, attitudinal and value changes of the villagers are very significant.

Table 1: Basic Information of the Villages

\begin{tabular}{|c|c|c|c|c|c|c|c|c|}
\hline $\begin{array}{c}\text { Description } \\
\text { Hs= House } \\
\text { F=Families }\end{array}$ & \multicolumn{2}{|c|}{$\begin{array}{c}\text { Mahakumbuk } \\
\text { Gollewa }\end{array}$} & \multicolumn{2}{|c|}{ Gonewa } & \multicolumn{2}{|c|}{ Talattewa } & \multicolumn{2}{|c|}{ Total } \\
\cline { 2 - 10 } & 1984 & 2013 & 1984 & 2013 & 1984 & 2013 & 1984 & 2013 \\
\hline Popn. & 179 & 478 & 183 & 510 & 180 & 332 & 642 & 1330 \\
\hline Fam.Nos. & 61 & 185 & 68 & 228 & 40 & 91 & 162 & 504 \\
\hline Family size & 2.93 & 2.58 & 2.69 & 2.2 & 7.0 & 3.6 & 3.96 & 2.63 \\
\hline High Land /F & 9.87 & 2.43 & 2.82 & 1.32 & 7.21 & 10.9 & 527.7 & 688.8 \\
\hline $\begin{array}{c}\text { Low } \\
\text { Land/Acs }\end{array}$ & 3.97 & 1.35 & 1.94 & 0.92 & 4.87 & 2.52 & 2.56 & 1.36 \\
\hline $\begin{array}{c}\text { Mud and } \\
\text { TimberHs \% }\end{array}$ & 41.0 & 3.0 & 63.0 & 2.0 & 62.5 & 0 & 62.0 & 5.6 \\
\hline Small Hs \% & 0.0 & 9.0 & 24.0 & 25.0 & 23.0 & 24.2 & 14.3 & 35.67 \\
\hline Medium Hs \% & 9.0 & 38.0 & 13.0 & 66.0 & 7.0 & 35.2 & 10.1 & 45.9 \\
\hline Large Hs \% & 7.0 & 50.0 & 0.0 & 6.0 & 7.05 & 40.7 & 13.5 & 13.0 \\
\hline
\end{tabular}

Source: Macro Survey of the Three Villages

The village community has gradually shifted from the traditional mode of society to that of modern society along with the "Green Revolution" followed by market liberalization. With these changes families have been exposed to high consumerism and have been trapped in market strategies (based on the focus group discussion). In the assessment of the villages and the transformation of the livelihood, the percentage of different types of houses, employment other than agriculture, in-migration and outmigration, percentage increase in $\mathrm{GCE} \mathrm{O} / \mathrm{L}, \mathrm{A} / \mathrm{L}$ and graduate level as a percentage of the labour force were given attention. According to the information the agriculture oriented employment pattern has been changed to service oriented employment. This particular change is not due to reasons consistent with development theories but due to other external factors, such as, the LTTE war, the impact of alienated modernization, etc. Modernization effects have played a dominant role for the change of the environment. The population of Mahakumbukgollewa (179), Gonewa (283) and Thalattewa (180) in 1984 had increased up to 478,510 and 332 by 2013 . The number of Families in the respective villages has increased from 61, 68 and 40 to 185,228 and 91 respectively. The average family size in the three villages has declined from 1984 to 2015 (see Table 1). The information witnesses that the challenges of the villages at micro level as well as at macro level have increased both vertically and horizontally.

\subsection{Farm and Non-Farm Employment}

Figures 1, 2 and 3 depict the change in non-farm employment of the three villages. Here the change had started in the 1980s. This was mainly because of the increasing demand for soldiers in the armed forces to fight the war against the LTTE. The numbers have intensively increased in the mid-1990s. Because of this intensive demand in the armed forces, the vulnerable youth in the marginalized communities got employment opportunities.

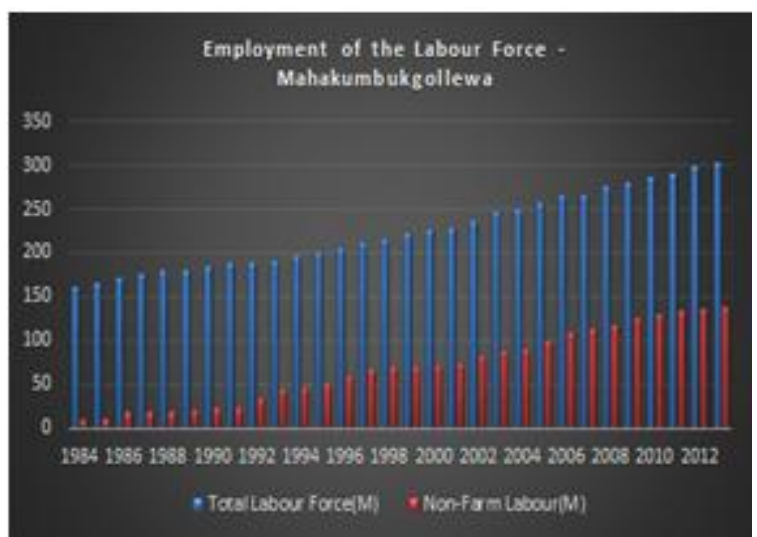

Figure 1: Employment Pattern in Mahakumbukgollewa Source: Macro Survey

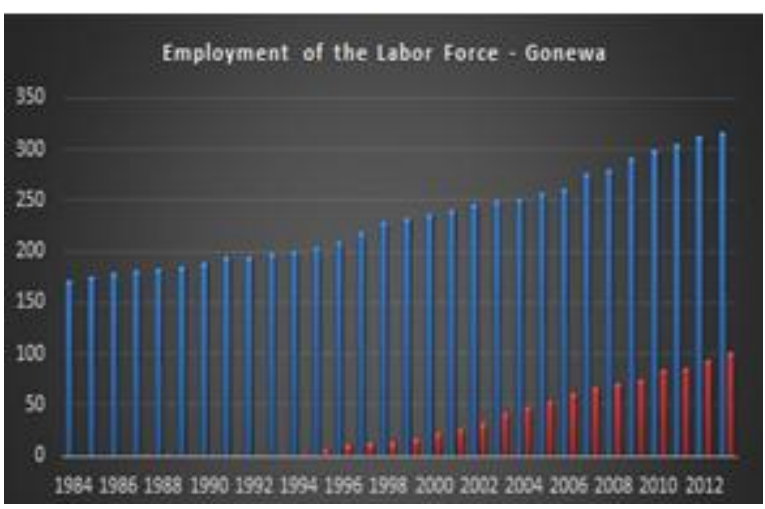

Figure 2: Employment Pattern in Gonewa Source: Macro Survey

\section{Volume 4 Issue 12, December 2015}




\section{International Journal of Science and Research (IJSR) \\ ISSN (Online): 2319-7064 \\ Index Copernicus Value (2013): 6.14 | Impact Factor (2014): 5.611}

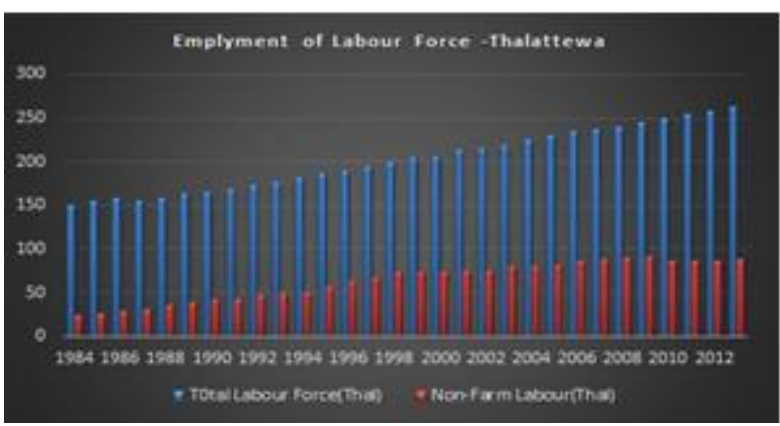

Figure 3: Employment Pattern in Thalattew Source: Macro Survey

The employment pattern in Sri Lanka was drastically changed due to the expansion of defence in the 1980s and thereafter (Jayawardena, 2011). These changes were more significant in the marginalized villages than in the others as the qualifications for the employment opportunities in the armed forces especially in the lower ranks are not competitive and the excess labour which was prepared to take a risk in their life has been matched with the demand in the defence sector (Jayawardena, 2011). Therefore, the issues of poverty, landlessness, lack of capital and unemployment have been managed through the employment opportunities in the armed services. In the sample villages, in the early period of the 1980s, the number of people employed in the armed services was less than 5 in each village. It has increased up to $38-58$ in 2013 (See Figure 4).

The factors affected the changes of the employment pattern are: 1. Irregularity of income earning capacity in agriculture, 2. Increase of employment opportunities in the armed services, 3. Easy recruiting conditions in the armed services under intensive war. 4. Less competitiveness of labour (based on the focus group discussion and participatory observation) 5. Impact of extended consumerism on livelihood of the rural village community under market liberalization. 6 . Inadequate income among families in the villages.

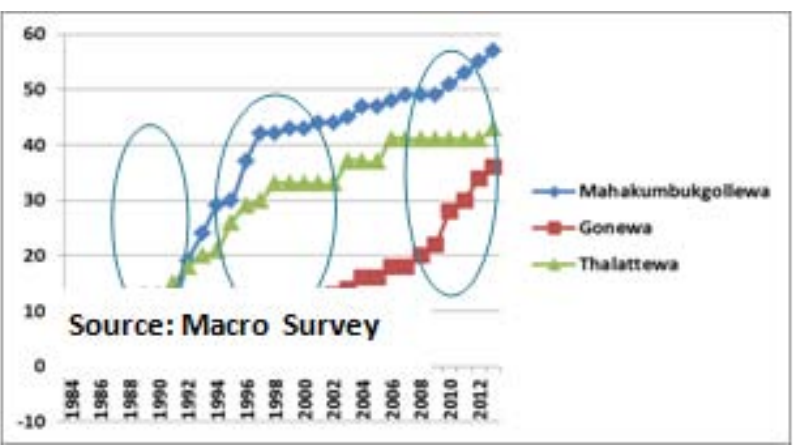

Figure 4: Number of people Employed in the Defence Industry

Among the three villages the fluctuation in Mahakumbukgollewa is high compared to the other two villages. Mahakumbukgollewa is a border line village in the war, and the intensity of the effects of war on this village had been comparatively higher than on the others. Therefore, in each year the number of people recruited to the armed forces has changed. The change in the recruitment to the defence sector in the Gonewa village has taken place in the 1990 unlike in the other two villages. The backwardness of Gonewa can be one of the reasons. However, the number of persons employed in the defence services in all three villages has been increased with time.

\subsection{Status of Houses in the Sample Villages}

The status of houses is a major indicator of the socioEconomic status of an economy and its transformation. In assessing the status of houses the types of the houses are identified as Mud and Timber (temporary), Small Houses (12), Medium Houses (3-4) and Large Houses (more than 4). In the 1980s large houses were very limited and many houses were of Mud and Timber. This has changed over the years.

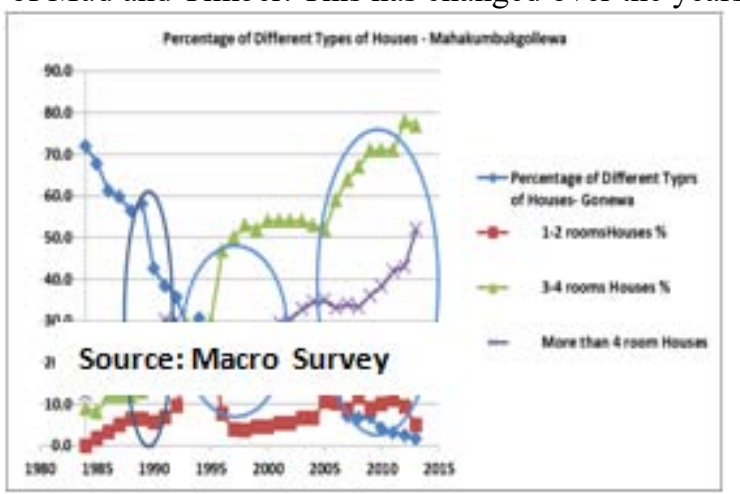

Figure 5: Percentage of different Types of HousesMahakumbukgollewa

In Gonewa, the changing pattern of houses has started at the beginning of the 1990s unlike in the other two villages. This particular change in Gonewa is associated with the pattern of employment. Refer to the changing pattern in Figure 4, 6 \& 7 . In Gonewa, recruitment to the armed forces has significantly started in the 1990s unlike in the other two villages.

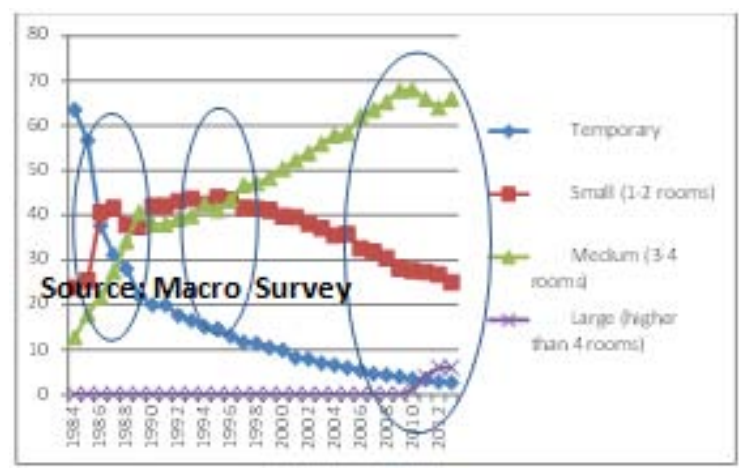

Figure 6: Percentage of different Types of Houses- Gonewa

In Thalattewa the particular change is little late compared to Gonewa. Compared to Gonewa, Thalattewa is an established agricultural village where vulnerability of the community is comparatively less (focus group discussion). Therefore, the Thalattewa community has reacted to the demand for labour forces in the armed forces little later and also with less intensity.

For all the changes within the villages the non-agriculture employment has affected significantly. Among the nonagricultural employment sources, employment in the defence services is important. The increase of employment in defence services is common in all three villages. 


\section{International Journal of Science and Research (IJSR) ISSN (Online): 2319-7064}

Index Copernicus Value (2013): 6.14 | Impact Factor (2014): 5.611

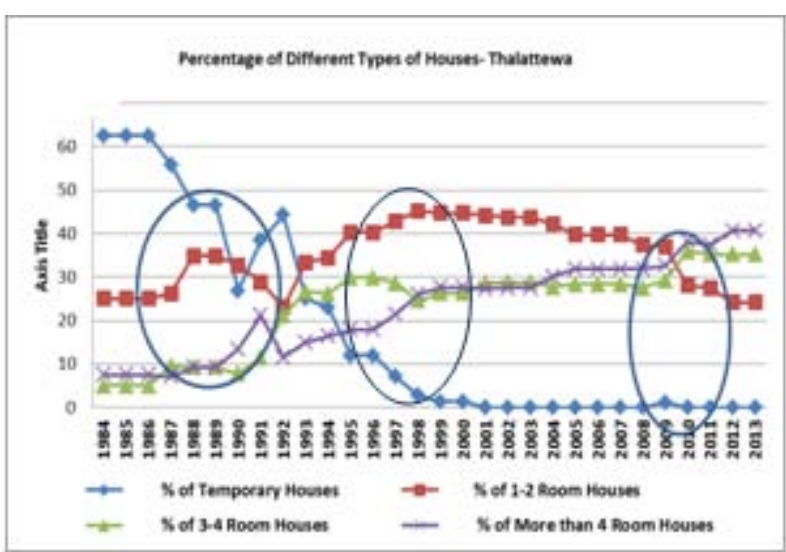

Source: Macro Survey

Figure: 7: Percentage of different Types of HousesThalattewa

Here the development of the villages can be measured by using the percentage change of medium and large houses and the temporary and small houses as it is an indicator of economic development in the context of Sri Lanka. Most houses of the three villages are built half way. This was significant in Gonewa .

In order to assess the socio economic standard of the people during the period from 1984 to 2013, in-migration and outmigration are also important. In 1984 the accumulated outmigration in Mahakumbukgollewa was This has increased up to 86 by 2013 . After 1989 the out migration has increased. In Mahakumbukgollewa in- migration includes only those who come to live in the village after marriage. In Gonewa this out-migration has increased from 5 to 99 during the period 1984-2013. In Thalattewa this change is from 3 to 38 . These figures witness that Gonewa and Mahakumbugollewa are not stable as Thallattewa as far as living environment is concerned. The other possible reason for higher migration is that Mahakumbukgllewa and Gonewa were with the impact of modernization which is higher when compared with Thalattewa. Commodification and capitalization in Mahakumbukgollewa is higher than that of Thalattewa. Mahakumbukgollewa as a village close to the A9 road benefitted from modernization. Gonewa as a poverty trodden village with an aggressive community due to historical reasons has been exposed to external community mainly because of less recognition as a Purana village in the village tank cascade (based on focus group discussion and participatory observation). The intensity of the number of employment in the armed forces also has affected the increase in out-migration. Under the circumstances, Gonewa, with more external affairs and the alienation among purana villages, the community has integrated with small business activities, such as, brick making and packeting of local products, such as, kurakkan, thala etc. However, these benefits have not contributed the community in the longer run because of the non-availability ground condition for sustainability.

\subsection{Changes of the Economic Status of Sample Villages}

Economic prosperity of the villages has been changed in the latter part of 1980s. The structure of employment in the minor tank villages was changed along with the employment opportunities in the defence related establishments resulted from the LTTE threat on all parts of the country. The exodus of money into the villages led towards vertical and horizontal expansion socio-economic dynamics of the villages. In the focussed group discussion where two retired Gramseva Niladharies said "The villages would never come out of their poverty syndrome unless there was Prabhakaran" When I inquired further they said that "the youth got extensive opportunities of employment in the armed services because of Prabhakaran's threat on the armed forces, thus villagers employed in the armed forces brought bulks of money (salary) when they return home during their leave after a continuous period of service (generally three months) in the war torn areas". In the sample there were about 10-15 families with soldiers and these families were able to build a house for themselves. This view is applicable to all three villages, though in different degrees. Employment in the armed forces has been drastically increased in the latter part of the 1980s. Therefore, the change in the prosperity of the villages and the change in number of people employed in the defence industry are associated with each other (see figure 4 , 5, 6 and 7). According to the authores observation the defence families were able to get improved the self-esteem that brought them the prosperity. Further, each village as a whole was also able to mobilize the diffused benefits of defence industry employment of the villages.

In the 1980s paddy cultivation in the low land and chena cultivation in high land had been common for all three villages. In the early period of the 1980 s black gram was the main cash crop of the farmers. Out of the total number of farmers in all three villages $81 \%$ was growing black gram. Other crops such as chili, red onion and vegetables were grown by less than $10 \%$. These crops were grown in the high land in Yala and Maha under rain fed condition (Jayawardena, 1988). This has been gradually changed towards cash crops, such as, chilli, maize, etc. Currently maize is the popular cash crop in all three villages. Farmers say they can earn more than SLR 100,000 per acre of maize for which the cost is only about SLR 17000/=. 'Kurakkan'e and chilli are the other extensive crops that they cultivate in the Yala and Maha. Generally there is a tendency to cultivate Kurakkan by families of less income as the cost of production is less. The families in Gonewa used to cultivate more kurakkan than other villages. Apart from this extensive cultivation, farmers do intensive cultivation in Akkarawela and in high land under Agro Well irrigation. For Intensive cultivation of cash crops Mahakumbukgollewa is prominent because of the high capital movement among villages. In Mahakumbukgollewa there was a farmer cultivating subsidiary food crops under an Agro Well even in the early 1980s. Since then the number of Agro Wells have increased during the last 30 years and currently in Mahakumbukgollewa there are about 20 Agro Wells and in Thalattewa and Gonewa there are 08 and 10 Agro Wells, respectively. In Mahakumbukgollewa Agro Wells have become a commonly use irrigation system. In this village many of the houses are provided with pipe borne water by using a well similar to Agro Well-constructed in the ,old homestead $^{\text {ee }}$ of the village (out of 47 farmers 24 are using pipe water for their day to day activities- Questionnaire Survey 2013/14). According to the observations and the information gathered through focus group discussions, agro wells have contributed to the village community for their day

\section{Volume 4 Issue 12, December 2015}




\section{International Journal of Science and Research (IJSR) \\ ISSN (Online): 2319-7064}

Index Copernicus Value (2013): 6.14 | Impact Factor (2014): 5.611

to day water requirements for washing, bathing and drinking purposes as well. During droughts the Agro Wells are beneficial for the community in the villages.

The Agro Wells guarantee water supply for cultivation. Therefore, farmers can invest on cash crop cultivation with less risk under guaranteed water supply. Cultivation under agrarian wells is capital intensive, therefore expenditure as well as income of Agro Well farmers are higher than those of the others

Table 2: Income Levels of Sample Villages

\begin{tabular}{|c|c|c|c|c|c|c|}
\hline Village & $\begin{array}{c}\text { Fam. } \\
\text { Size }\end{array}$ & \multicolumn{2}{|c|}{$\begin{array}{c}\text { Av.Income/Month } \\
\text { SLR }\end{array}$} & $\begin{array}{c}\text { Fam. } \\
\text { Size }\end{array}$ & \multicolumn{2}{|c|}{$\begin{array}{c}\text { Av. Income } \\
\text { Agro Well /F SLR }\end{array}$} \\
\cline { 3 - 4 } \cline { 6 - 7 } & & Family & Per Head & & Family & Per Head \\
\hline Mahakum & 3.77 & 33835 & 8974 & 3.44 & 37100 & 10785 \\
Buk gollewa & & & & & & \\
\hline Gonewa & 4.95 & 34418 & 6953 & 4.50 & 35470 & 7882 \\
\hline Thalattewa & 3.85 & 25071 & 6512 & 3.50 & 36500 & 10428 \\
\hline Average/S L & 4.2 & 1,65640 & 39438 & - & - &. \\
\hline
\end{tabular}

Sources: 1. Questionnaire Survey

2. Annual Report Central Bank of Sri Lanka, 2014

3. Department of Census and Statist (Population 2001)

According to Table 2 family income of Agro Wells is higher than that of the others, which indicates that Agro Wells have transformed these villages into a business community.

However, in order to construct an Agro well, farmers need to invest more than SLR 100,000. Some farmers who were not able to find the total expenditure had to abandon the wells. During the field survey there were 4 such abandoned wells in Gonewa. A farmer who was successful in the construction of an Agro Well was able to increase the level of income. However, according to the questionnaire survey and the focus group discussion the benefits of Agro Wells have helped in uplifting the village community only in Mahakumbukgollewa. (Refer to Table 2). Agro Wells and economic conditions of villages are closely associated with each other. Yet, the income level of the ,Agro well' farmers as well as average famers have been significantly low compared to the average income of a Sri Lankan (Refer to Table2). Further, it has been scientifically proved that excessive extraction of ground water leads to the creation of problems in the water table of the area (Dharmasena, 2004). Under natural restrictions phenomena including the restricted water table condition, unlimited extraction of water through Agro Wells in these Purana villages is also an issue to be considered. Therefore, Agro well as an irrigation system cannot be considered as a sustainable solution to the problems.

\subsection{Income Inequality of Sample Villages}

Modernization that leads to commodification and capitalization along with new technology has changed the homogeneous nature of the community in the areas of land ownership, level of income, etc. Commodification and capitalization have been resulted from tracterization and the use of chemicals and chemical fertilizer in agriculture. (Issues are discussed in the forthcoming sections). Further the agro well and non-farm employment, especially the drastic increase in employment in national defence are the main factors that have affected income inequality. For example, Gonewa which was a highly backward village among the three villages has come forward because of the families earning high income from the employment in the military services. The income differences have created a petty bourgeois class in the villages has made further complications in the political economy system (see section 7).

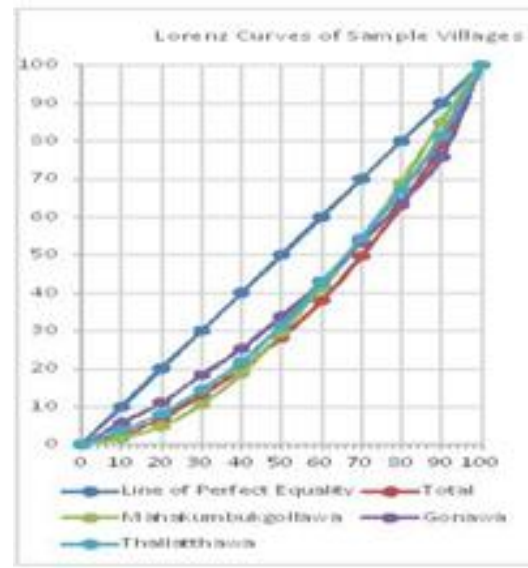

Figure 8: Income Inequality of Sample Villages Source: Based on Income gathered in Micro Economic Survey.

\subsection{Age at Death of Different Generations}

In Sri Lanka the percentage of population over 60 is reported $12 \%$ whereas in the three villages the percentages are Mahakumbukgollewa, 9\%, Gonewa, 7.8\% and in Thalattewa, $8.3 \%$. Further according to the questionnaire survey, the average age at death of parents in all three villages is 69.9. This was 86.1 for grandparents. This particular information is comparatively low in Mahakumbukgollewa and Gonewa. In Mahakumbukgollewa the level of income is comparatively high and therefore, generally life expectancy should also be high. Yet the age at death of the house holders ${ }^{\text {ee }}$ fathers in Mahakumbukgollewa is comparatively low. In Gonewa economic standard is comparatively low, so the lower age at death is justifiable. In Thalattewa the age at death is comparatively higher. The reason can be the difference in the livelihood. Comparatively, Thalattewa maintains Purana Village traditions and the community is not trapped in high consumerism as the other two villages.

Overall, in all three villages the parents of householders had died at the age of 69.9 whereas the grandparents those who died were at the age of 86.1. This information indicates that the life expectancy is on the decline. According to the national level statistics the country level life expectancy is 74.6 years. Therefore the present socio-economic condition of the villages needs to be revisited and readjusted against the lower life expectancy.

\subsection{Agrochemical Use and Health Hazards}

The village communityes declining age at death itself is an indicator of health hazards. Among the villages about 15.4 percent are suffering from non-communicable diseases. Out of non-communicable diseases Chronic Kidney Disease (CKD) is major as it is more than $5-6 \%$ of the population. In the focus group discussion it was mentioned that villagers do

\section{Volume 4 Issue 12, December 2015}




\section{International Journal of Science and Research (IJSR) \\ ISSN (Online): 2319-7064 \\ Index Copernicus Value (2013): 6.14 | Impact Factor (2014): 5.611}

not like to disclose their diseases because they are labelled as sick and therefore, it is a disadvantage for them in their socio-economic lives (Villagers focus more on their current conditions than the long term implications of their lives and as a result there is a tendency hide their health conditions until they become critical). Therefore, the actual number of people suffering from diseases is more than the numbers reported. The CKD sufferers are definitely greater than the reported number. According to the macroeconomic survey, the percentages of population suffering from noncommunicable diseases of the three villages are Mahakumbukgollewa-13\%, Gonewa $16 \%$ and Thalattewa$12 \%$. Further, according to the information, out of 190 cases of people affected by non-communicable diseases $12(6 \%)$ are below the age of 15 years. Gonewa which is of a lower standard of socio economic conditions is comparatively more vulnerable than the others as far as the health condition is concerned $(16 \%$ were affected by non-communicable diseases). Therefore, lower socio-economic condition and health issues are closely associated with each other.

The farmers do not practice standard methods in buying, during the time of application and in follow up actions with respect to the use of agrochemicals in farming. During the group discussions it was revealed that farmers generally follow instructions given by the agrochemical dealers and do not consult agriculture officials. As a result, the use of agrochemicals is subjected to the decisions of the agrochemical dealers and company agents who are motivated by profit and thus farmers tend to ignore the safety measures as well as standards of chemical concentrations of agrochemicals. Therefore, there is a tendency towards over use of agro chemicals without following the standard methods, thus both weedicide and insecticide are used indiscriminately. In all three villages for the last 5 years up to $2013 / 14$ in which they have cultivated substantial amount of paddy lands, average use of insecticide per acre $(0.4 / \mathrm{H})$ is $0.65 \mathrm{~L}$ that cost the farmer LKR 965.00 (The same for weedicide, about $0.75 \mathrm{~L}$ and LKR 958). This amount is comparatively higher in Gonewa and Mahakumbukgollewa. In the follow up study, it has been found that farmers have reported lower amount of agrochemicals because of country level criticism and the actual use of agrochemicals could be more than the reported amount (based on focus group discussion). Further, in the field survey it has been observed that farmers used to wash-out the agro chemical cans, the spray tanks and other instruments to the tank. During the period of droughts the agrochemical concentration in the tank water as well as in the water table is high. It has also been observed that farmers used to apply weedicides before harvesting paddy and other grains to enhance the temperature conditions and to protect from insects and keep the physical quality of the products that enable them to get a better price in the market. Because of this, paddy and other grains produced by farmers are not healthier. A Furthermore, indiscriminate use of insecticide and weedicide are damage to the quality of the ground water and damage, the lives of the community and the environment.

Under these conditions, on one hand the village community has gradually become victims of non-communicable diseases and become victims of health hazards and poverty syndrome on the other. Indiscriminate use of agrochemicals, chemical fertilizer and other inputs to get higher production to satisfy high consumerism has been forced by the existing political economy at different levels. The CKD, cancer and other noncommunicable diseases that have affected children, youth and adults witnessed the danger in the society as far as health is concerned. There is a fear psychosis among the people in the dry Zone especially because of CKD. The minor tank villagers who are affected by drought and poverty syndrome are more vulnerable to these health hazards (focus group discussion).

The use of agrochemicals and fertilizer has become a dichotomy in the livelihood of the village community. On one hand, in order to continue the present production, productivity and to enjoy the life style under commodification and capitalization, use of agrochemicals and fertilizer have become essentials and the empirical evidence witness that as far as the long run is concerned the present pattern of use of these inputs is signalling a disastrous future for the community as well as the environment on the other.

\subsection{Excessive Intervention of the Government}

Minor tank villages are poverty trodden villages. Therefore, there is an overwhelming interest among policy makers, the government and non- government officials, academics and researchers. Within this spectrum, the village community in nature can easily be convinced for various new packages, and the community at individual level as well as at community level is subjected to political economy exploitation. There are numerous government officials intervened in various development related activities of technical, administrative, development, etc., who are officially linked with different line ministries. Among such officials, gramaseva niladhari, Krushi Paryesana nispadana sahakara, development officer, Krushi Upadeska, Samurdhi Niladhari, Economic development Officer (Representative of the economic development ministry) etc., are important. Apart from them NGOS are also intervened in different activities. With respect to these officers, there is hierarchy from village level to national level. At each level of hierarchy, there is a linkage with the political economy and the decisions are made in line with the political economy concerns. Under these circumstances, government intervention through these officials is not productive as far as sustainable welfare of the community is concerned. It happens because the origin of intervention is to achieve political economy objectives of the intervened parties rather than the actual requirement of the community. Under these circumstances what is emphasized in the projects will not be achieved as expected. If a cost benefit analysis of government intervention is done, the cost to the economy is greater than the benefits. Various government officials unnecessarily intervene in community activities, and as a result the conditions become confusing for the community as well as for the officials as far as the real requirements are concerned. Finally the community becomes vulnerable as far as their long term welfare is concerned.

\subsection{Issues of Agriculture}

As far as cost of production is concerned community faces numerous difficulties. Among them the gap between actual 


\section{International Journal of Science and Research (IJSR) \\ ISSN (Online): 2319-7064 \\ Index Copernicus Value (2013): 6.14 | Impact Factor (2014): 5.611}

cost and the calculated cost of production is important. The cost of production of paddy per Acre of paddy land $(0.4 \mathrm{Ha})$ in the villages of Mahakumbukgollewa, Gonewa and Thalattewa is SLR 33278, SLR 26275 and SLR 28227 (Av. SLR 29260). This includes, ploughing, land preparation, seed paddy cost, broadcasting cost of seed paddy, fertilizer cost, cost of agrochemicals, cost of harvesting and transportation. Compared to traditional cultivation, tracterization' (SLR 7500.00/Acre for ploughing and SLR 8000/Acre for harvesting (.04Ha) and intensive use of agrochemicals (SLR 958.00/Acre for insecticide and SLR 965.00/Acre for weedicide and fertilizer) are the two main reasons for the higher cost of production. Comparing with the total cost in 1983/84 (SLR 3308.00/Acre), the cost in 2013/14 (SLR $29260.00 /$ Acre) is comparatively higher. Even with the adjustments after considering the inflationary effect and making adjustment for fertilizer subsidy, the increase in the cost of production of paddy seems higher. Even though the real cost of production compared with 1983/84, seems less when one considers the fertilizer subsidy and other socio economic changes it is difficult to conclude that cost of production has been declined. Excessive use of agrochemicals and ,tracterization' has cost for the farmer more as there was no mechanism for them to employ the saved labour. Out of the total cost about $50 \%$ is spent for the use of tractors for ploughing, harvesting and transportation. For example, per acre land farmers spend SLR 17,500 as tractor charges. In all three villages there were 23 families with zero low land (in Thalattewa and Mahakumbukgollewa 7 each and Gonewa 6). They may have sold their land plots to the others. In mahakumbukgollewa, Thalattewa and Gonewa the number of families with more than 2 acres of land are 20, 9 and 19 families respectively. The number of families with less than 2 acres are Thalattewa 29, Gonewa 16 and Mahakumbukgollewa 17. Therefore, unequal distribution of landownership is more in Gonewa and mahakumbukgollewa, whereas Thalattewa has been able to maintain fairly equal distribution of land. The less low land and landlessness is an outcome of heavy mechanization which cost to the farmer more than SLR 20, 000/Acre which cannot be tolerated especially for the poor farmers who are struggling for survival. The fragmentation of paddy land in the minor tank villages is also an issue. The fragmentation of paddy land has become an issue in use of tractors and in general, it has led to high cost of production and inefficiency of land use (During the focus group discussion held in the paddy field at the time of land preparation the farmers came out with their problems in using tractors as paddy lands spread over Puranawela and Akkarawela). The intensity of fragmentation of paddy land has led to issues of water management as well (focus group discussion.).

\subsection{Socio-Economic Vulnerability of the Community}

The communities of minor tank villages have faced a triangle dichotomy as an individual, family and also as a community. Firstly, the resources as well as the feasibility for high economic growth are restricted. Secondly these villages had continued with an agriculture dominated traditional system along with a simple life style which has been moderated by Buddhism. This was compatible with the restricted village economy. Thirdly, in 1960s the "Green Revolution" pushed by the modernization has gradually changed the thinking pattern of the people as well as the socio-economic activities at individual level, family level and community level. All these three dimensions of the livelihood are intertwined with each other in the current context and has become a dichotomy. Thus the community is entangled with this dichotomy and has undergone socio-economic vulnerability as an individual, family and also as a community.

All the minor tank villages are based on rainwater. Flooding and droughts are common features (according to the macroeconomic survey there were 05 droughts and 04 flooding that led to the problems in agriculture along with socio-economic vulnerability).

In the traditional system the chena cultivation and the paddy cultivation aligned with their simple life style guided by Buddhist philosophy have complementarily helped them to survive under climatological vulnerability which is a common feature as a cycle in this part of agricultural settlements (Darmasena, 2004). The intensive current vulnerability in these villages is a result of the following factors (based on macro survey and focus group discussion). 1. The change of the simple life style to commoditised and capitalized life style. 2 . The increase in population $(105.6 \%$ annual increase 3.64). 3. The increase in government intervention both horizontally and vertically which became a bottleneck in decision making. 4. The conflict of interest of the community with regard to sustainable development. 5 . High capital intensive cultivation under modernization. 6. The fear psychoses of non-communicable diseases especially, CKD that linked with present modernization pushed by market liberalization and globalization.

The Ancient civilization in Sri Lanka especially during the period of Anuradhapura was based on the concept of "Wewai Dagebai Gamai Pansalai" where the focus was on the spiritual development of the community. The majority of the community was well established in their life. The Buddhist culture provided a meaning to life with a reasonable explanation that includes both birth and death. It was philosophically and empirically consistent. Along with the changes in the socio-economic and political conditions at micro level and macro level, the established system of the community has been gradually changed. In the focus group discussion it was revealed that the majority of the male are with scapegoat behaviour when it comes to religious activities. In other words they are not closed to the temple unlike in the traditional system. The villagers are also gradually getting away from the religious activities due to confused thinking dichotomy in their commoditised and capitalized life and religious thoughts. In 1983/84 the farmers in the selected minor tank villages used to utilized agrochemicals, chemical fertilizer and machinery for land preparation and harvesting. The new system has mechanized the community without any compatible adjustment in the original base of the socio-economic structure, thus it has cost to the village community in the short run as well as in the long run. In 1983/84 per acre (Ha) yield of three villages (Mahakumbukgollewa, Gonewa and Thalattewa was $1158 \mathrm{~kg}$ $(2860 \mathrm{Kg}), 1274 \mathrm{~kg}(3148 \mathrm{Kg})$ and $1273 \mathrm{~kg}(3144 \mathrm{Kg})$ respectively. This has been increased to $2100 \mathrm{~kg}(5187 \mathrm{~kg})$, $1950 \mathrm{~kg}(4816 \mathrm{~kg})$ and $2200 \mathrm{~kg}(5434 \mathrm{~kg})$. Comparatively, 2014/15 Maha, was a favourable year for agriculture.

\section{Volume 4 Issue 12, December 2015}




\section{International Journal of Science and Research (IJSR) \\ ISSN (Online): 2319-7064}

Index Copernicus Value (2013): 6.14 | Impact Factor (2014): 5.611

However, when compared the average yield of the sample with that of Sri Lanka, still less (Av yield for Sri Lanka $2352 \mathrm{Kg} / \mathrm{Ac}(5809 \mathrm{~kg} / \mathrm{Ha})$ in $2013 / 14)$. Therefore, as far as Sri Lanka as a whole is concerned these villages are marginal.

Along with the modernization effects, the established religious bond, the collectiveness of the farming community/villagers and the bond between the village community and the tank have been gradually weakened. They are reluctant to go to the traditional pattern of collectiveness. For example, in Mahakumbukgollewa and Gonewa villages the farmers have ignored even the maintenance of tanks which is still the heart of the village. Some of the farmers have not even cleared their allotted tank bund during the Maha season. Thalattewa which is comparatively better also witnessed negligence of tank duties which has been traditionally maintained by ancestors without any failure. During the festival season participation of the villagers was limited only for a lesser number of people. (Avurudu Festival in Mahakumbukgollewa, there was only 20-25 people). The capitalized and commoditised villages were subjected to exploitation by petty bourgeoisies of within, adjoining or outside people who get the opportunity because of the unstable socio economic conditions under the present modernization. Out 30 years, Gonewa received rainfall to fill the tank that brings prosperity to village for only 12 years. The other 18 years Gonewa village was not with socioeconomic stability and was exposed to the exploitation.

All three villages as traditional village community are less prepared for modernization. The village community is alienated to modernization. They are not a part of it. However, along with the liberalization and globalization, they are forced to the new phenomena and have become victims of it. Whenever the villagers get better harvest/income, the villagers, get into the modern marketing traps and become victims of socio-economic vulnerability in two ways. Firstly they are exploited in selling their products and secondly in spending income for various purposes. During the Maha (2014/15), most of the farmers had to sell their rice for Rs.30/ to $35 / \mathrm{Kg}$ and in the Yala (2015) between $20 /-30 / \mathrm{Kg}$., whereas the guaranteed price is Rs.40/ - 50/Kg. Further among the capital items (including the durables) bought by farmers, (less than SLR.300,000) were under leasing arrangements (10 out of $35(29 \%))$. In Gonewa this number is 27 out of $30(83 \%)$. In Mahakumbukgollewa this number is 13 out of 35 (37\%). In Mahakumbukgollewa five families had bought tractors and other vehicles valued more than SLR 300,000 under leasing arrangements. Those who bought under leasing arrangements face serious problems in paying their instalments. This had been more critical in Gonewa. In Gonewa out of 27 who purchased on leasing arrangement, 12 were subject forceful seize their leased assets to the companies. This number in Mahakumbukgollewa was 05. In Thalattewa there has been no such seizing.

The trap in high consumerism and the competition among villages were the main reasons for socio-economic vulnerability of the community. In the present context, the community is motivated for high consumerism by the competitive market. Because of the chain of political economy, the community is pushed for individual interest rather than the community interest and finally the community is transforming towards commodification and capitalization. In the minor tank villages, because of the less potential under restricted topographical and climatological conditions (based on the participatory observation), there is a need of functioning the community as a collective entity that helps in maximizing available resources and to survive under difficult situations such as droughts, floods and other natural disasters. The commodification and capitalization have interrupted the collective behaviour of the community which is a requirement, as far as the ground conditions of these marginalized villages are concerned.

In the process of transformation of the community within the dilemma of modernization and traditional system some farmers have become marginalized in paddy farming (E.g. zero low land or less low land). These famers do not enjoy full rights as farmers in the village. Therefore, the bond of such families with the community is less and as a result generally they are not willing to abide by rules and regulations of the traditional villages. In all three villages those who are with less low land have ignored the collective agreements, such as, clearing of the tank bund, participating in other collective activities, etc. In certain occasions, they have encroached even the catchment area and other reservations of the tank. In Gonewa the farmers with less or without low land used to live in the upper reservations that interrupt the tank and the community. These families protest the increase of the height of the tank bund and influence to make lower spill overs/emergency spill overs to prevent flooding in their residential areas during the rainy seasons. The same families excavate Agro wells in the tank reservations. In Gonewa, this has become a problem for the officials as well as the community. In the discussion with irrigation engineers, it was reported that illegal encroachments cannot be dealt with, as the involved parties linked with the political economy. Therefore, traditionally maintained protected measures in the village tank systems have been violated despite appointed officials are assigned to look after tank and its environment.

The youth are over ambitious on non- farm employment despite of their lower academic qualifications and lack of professional skills. Under such conditions there is a conflict in dealing with the traditionally existed system in the village. In Gonewa village it has been observed that there were youth wearing ear rings and there were youth with different types of haircuts roaming in the village in spite of the poverty and other socio-economic issues in the area. The confused livelihood has gradually developed to social vulnerability. Out of the three villages Gonewa has been badly affected. In the focus group discussion it was also revealed that the younger generation does not prefer to engage in farming. Their thinking is quite different from their parental generation who liked the village and the traditional socioeconomic system which has been compatible with the level of available resources and the topographical environment. Thus a gap has been observed between parents and the children. This particular gap was critical in Gonewa, comparatively lower income generating and little inferior when compared with the other two villages. Therefore, vulnerability due to high consumerism that aligned competition is greater among families and individuals

\section{Volume 4 Issue 12, December 2015}




\section{International Journal of Science and Research (IJSR) \\ ISSN (Online): 2319-7064}

Index Copernicus Value (2013): 6.14 | Impact Factor (2014): 5.611

compared to the urban society. This particular feature was observed in all three villages.

\section{Discourse of Development of Minor Tank Villages}

The minor tank villages have historically survived as rural settlement where the communities have been preferred to run their own independent simple life on their owned choice. In the historical setting all the farmers were equal and have shared their low land without a significant difference. The Chena cultivation which has been a supplementary cultivation mainly in the yala also continued season by season collectively as a community. Along with the time as the Puranawela (the old paddy land became insufficient, farmers extended their paddy land with additional land supported by Goda Sorrowwa (upper Anicut). The aswaddumization as well as the cultivation of this land has been the same as puranawela and therefore, the equality of the community had been maintained until the introduction of the Green Revolution Package in 1960s. At this juncture economic growth and development indicators of the contemporary era labelled these settlements as poverty trodden communities. Under these circumstances these villages were offered different packages of development by using political economic hierarchy of different layers of the community both formal and informal. Use of agrochemicals, fertilizer and tracterization of activities have made the cultivation easier and high productive but costlier and followed with secondary and tertiary problems as discussed under section 9. In the traditional system all the activities of farming had been done either manually or/and using animals draft. Because of the mechanization of farming the collectiveness in the society which is a necessary condition for the survival of the community in the context of nature given restrictions overrun by the competition and has challenged the society in its sustainability. At present, the community has failed to understand scope for the existence at individual level as well as at village level, and pushed them into a chain of problems (see section 9).

\section{1 Level of Satisfaction of the Community}

In order to assess the welfare of the community a set of statistical analyses were done using the information of selected dummy variables. Here the information gathered from the selected villages, regarding non availability of financial resources, increase of diseases, deterioration of values and attitudes, non-availability of proper guiding system and non-availability of basic needs (Likert scale) was used to estimate the overall satisfaction of the selected communities. A total score was obtained using the responses for the above aspects with a maximum score of 25 , a score of equal or less than 19 was taken as satisfied and a score of equal or less than 20 as not satisfied. This score was used for a chi square comparison of overall satisfaction, between the families where the sole source of income was farming and other families. The null hypothesis is that there is no significant difference in the overall satisfaction regarding the welfare of the community between the families where the sole source of income is farming and the other families. The null hypothesis was tested using the chi-square test. The results are shown below (table 3 and 4)

Table 3: Level of Significance of Comparison Occupation * Satisfaction Crosstabulation

\begin{tabular}{|c|c|c|c|c|}
\hline & & \multicolumn{2}{|c|}{ Satisfaction } & \multirow[b]{2}{*}{ Total } \\
\hline & & yes & no & \\
\hline \multirow[t]{6}{*}{ Occupation } & Count & 24 & 49 & 73 \\
\hline & \% within Occupation & $32.9 \%$ & $67.1 \%$ & $100.0 \%$ \\
\hline & $\%$ within Satisfaction & $38.7 \%$ & $68.2 \%$ & $53.7 \%$ \\
\hline & Count & 38 & 25 & 63 \\
\hline & \% within Occupation & $60.3 \%$ & $39.7 \%$ & $100.0 \%$ \\
\hline & $\%$ within Satisfaction & $61.3 \%$ & $33.8 \%$ & $46.3 \%$ \\
\hline \multirow[t]{3}{*}{ Total } & Count & 62 & 74 & 138 \\
\hline & \% within Occupation & $45.6 \%$ & $54.4 \%$ & $100.0 \%$ \\
\hline & $\%$ within Satisfaction & $100.0 \%$ & $100.0 \%$ & $100.0 \%$ \\
\hline
\end{tabular}

Chi-Square Tests

\begin{tabular}{|c|c|c|c|c|c|}
\hline & Value & df & $\begin{array}{c}\text { Asymp. Sig. } \\
\text { (2-sided) }\end{array}$ & $\begin{array}{l}\text { Exact Sig. } \\
\text { (2-sided) }\end{array}$ & $\begin{array}{l}\text { Exact Sig. } \\
\text { (1-sided) }\end{array}$ \\
\hline Pearson Chi-Squar & $10.265^{0}$ & 1 & .001 & & \\
\hline Continuity Correcai & 9.189 & 1 & .002 & & \\
\hline Likelihood Ratio & 10.379 & 1 & .001 & & \\
\hline Fisher's Exact Test & & & & .002 & .001 \\
\hline $\begin{array}{l}\text { Linear-by-Linear } \\
\text { Association }\end{array}$ & 10.190 & 1 & .001 & & \\
\hline $\mathrm{N}$ of Valid Cases & 136 & & & & \\
\hline
\end{tabular}

a. Computed only for a $2 \times 2$ table

b. 0 cells $(.0 \%)$ have expected count less than 5 . The minimum expected 72 .

According to the information from all three villages, $67 \%$ of the families whose sole source of income is farming have said that they are not satisfied whereas only $39 \%$ of the other families are dissatisfied. On the other hand only $32.9 \%$ of the families whose sole source of income is farming as opposed to a percentage of $60 \%$ of the other families being satisfied with the welfare of the community. The " $p$ " value for the above comparison is only 0.001 and the null hypothesis is

\section{Volume 4 Issue 12, December 2015}




\section{International Journal of Science and Research (IJSR) \\ ISSN (Online): 2319-7064}

Index Copernicus Value (2013): 6.14 | Impact Factor (2014): 5.611

therefore rejected. Thus there is a significant difference in the levels of satisfaction between the families whose sole source of income is farming and the others according to the data obtained from the three villages Mahakumbukgollewa, Gonewa and Thalleththewa.

In the study while addressing the conceptualized model, the researcher proposed the following to the community:

"Allow those who wish to leave the villages while allowing the rest of the community to get organized themselves in line with Purana Village system with appropriate modernization which is in consistent with the concepts of sustainable development, Gross Human Happiness, Green Development based on a simple life style supported by Buddhism and collectivism that lead to spiritual development"

This proposal was accepted by $90 \%$ of the community (either agree or strongly agree according to the Likert scale score). The validity of generalization of the above observation was tested using a non-parametric test - goodness of fit test and the results are shown in the following table.

Table 4: Goodness of Fit Test for the observation

Descriptive Statistics

\begin{tabular}{|l|c|c|c|c|c|}
\hline & $\mathrm{N}$ & Mean & Std. Deviation & Minimum & Maximum \\
\hline FINAL & 136 & 0.93 & 0.25 & 0 & 1 \\
\hline
\end{tabular}

FINAL

\begin{tabular}{|c|c|c|c|}
\hline & Observed & Expected & \\
& $\mathrm{N}$ & $\mathrm{N}$ & Residual \\
\hline Do not agree & 9 & 13.6 & -4.6 \\
\hline Agree & 127 & 122.4 & 4.6 \\
\hline Total & 136 & & \\
\hline
\end{tabular}

Test Statistics

\begin{tabular}{|c|c|}
\hline & FINAL \\
\hline Chi-Square(a) & 1.729 \\
\hline $\mathrm{df}$ & 1 \\
\hline Asymp. Sig. & 0.189 \\
\hline
\end{tabular}

a 0 cells $(.0 \%)$ have expected frequencies less than 5 . The minimum expected cell frequency is 13.6.

According to the chi-Square analysis "p" value $(0.189)$ is greater than 0.05 therefore the proposal is agreeable for any such population.

\section{Proposed New Development Model}

On the basis of the analyses under section 10 the researcher proposes the model given in Figure 9. According to the model, ontological base (human nature), epistemological formations (Buddhism and Marxism), Life philosophy (Individual and as a community), sustainable development (four types of sustainability) and spiritual development are the different stages of community development. Here, the concept of development is interpreted on the basis of Gross Human Happiness $(\mathrm{GHH})$ taking the spiritual development as the end task of human endeavour.

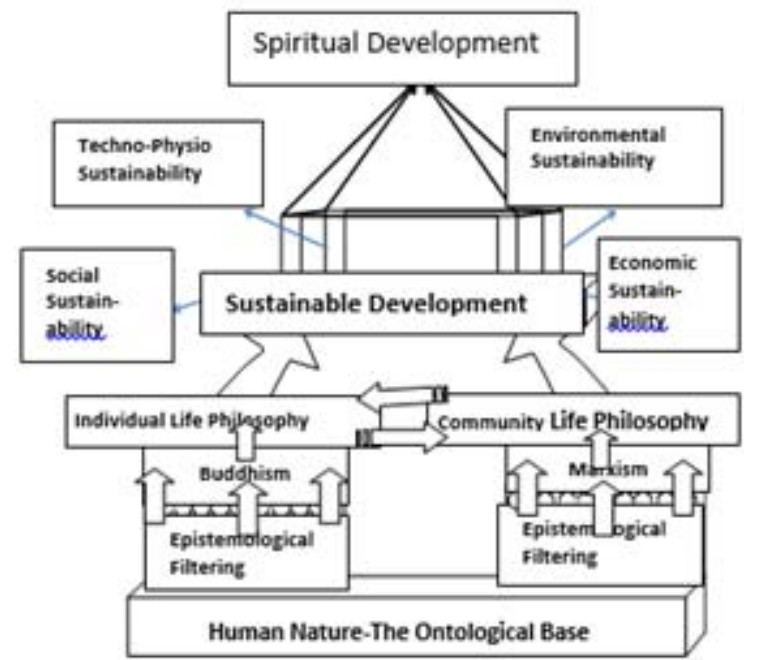

Figure 9: The Proposed New Model of Development for Minor Tank Villages

Note: Acknowledged the contribution made by Prof. CM Madduma Bandara)

According to the model, the ultimate destination of the human being as an individual and also as a community is to reach supreme spiritual development (ontological assumption). This goal is compatible with the philosophical view of human as the Supreme Being when compared with animals and the other living beings in the world. In order to reach this higher spiritual status, four types of sustainable development (social, economic, environmental and technophysio) are to be fulfilled (epistemological assumption). In this endeavor, firstly, the individual path for spiritual development via sustainable development based on the wisdom of Four Noble Truths which includes the Nobel Eight Fold Path in Buddhism referred in the model need to be incorporated in the life philosophy at an individual level (see section 7 and Figure 9). Secondly, considering the need of continuation of a level of consumption as well as production for the survival as an individual and also as a community, Marxism need to be appropriately incorporated with production and consumption to lead the economy towards sustainable development without allowing bourgeoisies to dominate the community for commodification and capitalization as experience in the present day context. Thus the individual life philosophy based on Buddhism and the philosophy for the community based on Marxism enable to sustain economic, social, and environmental and techno - physical sustainability and reach spiritual development of human beings.

As depicted in Figure 9, ontological conditions of human beings (which are the barriers for generating philosophical bases) are filtered via epistemological inputs and identify Buddhism as the base for individual life philosophy and Marxism as the philosophy for the community as an organism. According to the model, thereafter, the community as well as the individuals interact with each other and transform to mutually co-existed conditions that enable to reach socio-economic, techno-physio, and environmental sustainability. In this model both the collective and individual pathways are considered complementary to each other. Finally, sustainable development as an individual and 


\section{International Journal of Science and Research (IJSR) \\ ISSN (Online): 2319-7064}

Index Copernicus Value (2013): 6.14 | Impact Factor (2014): 5.611

as a community enables to reach spiritual development which is the saturated point as an individual as well as a community

\section{Conclusion}

Development theories have failed to interpret the current patterns of production, consumption and other socioeconomic conditions of minor tank villages of Sri Lanka similar to the sample villages of Mahakumbukgollewa, Gonewa and Thalattewa. During the last thirty years there has been a change in the production, productivity and level of income of the three villages. Yet, despite the difference between the villages, they have being facing a dilemma in the context of development trends. The traditional system was changed along with the green revolution in which farming was indiscriminately mechanized and modernized. Even though the production and productivity have increased through capitalization and commodification there has been a significant increase in the cost of production. As a result of modernization there has been a significant increase in leakages (withdrawal) to outside of the community. This percentage of withdrawal is more than $50 \%$ (tractor share, cost of agrochemicals, fertilizer, etc.).

Most of the farmers are unable to tolerate the heavy capital expenditure, thus some farmers have sold their paddy land. The outcome of such a tendency is increasing landlessness, poverty and inequality among the farming community. Therefore, in spite of the favorable impact of modernization on economic growth, there has been a dichotomy between the level of modernization and socio-economic issues. Under these circumstances, there is a need for a new paradigm of development that addresses the current context of minor tank villages.

The model in Figure 9 is an ideal model of development for marginalized rural communities, such as, the sample minor tank villages. This new model of development is based on, the Gross Human Happiness (GHH) index along with the suggested approaches of sustainable development. The Model has explained the theoretical base of sustainable development which is the missing piece in the concepts of sustainable development.

The following are forwarded for further studies. 1. Identify a feasible plan to execute the proposed model in a representative village. 2 . Studies to test the model in other poverty trodden societies 3. Study on possible issues pertaining to sustainability of such a model. 4. Explore the possibility of reinterpretation of current economic development aligned with the new model.

\section{Acknowledgment}

General Sir John Kotelawala Defence University for giving the grant to conduct the research, Department of Social Sciences for facilitating the study, the villagers of Mahakumbukgollewa, Gonewa and Thalattewa for giving information during the questionnaire survey and granting permission for the photographs and finally, Anurdhapura district and provincial officials and the Grama Niladharies for their help in finding secondary information of the villages are acknowledged.

\section{References}

[1] Allen, Kelle, (1991) The Human Development Index: "Handle with care" Population and Development Review Vol. 17, No.2 pp315-324.

[2] Beck, Thorstan et al. (2001) "New Tools in comparative Political Economy": The data Base of Political Institutions, The World Bank economic Review, 15(1) pp, 165-176.

[3] Althusar, L. (1998) Ideology and Ideological State Apparatuses Eds. J Rvekin \&M. Ryan Literary Theory an Anthropology Malden Blackwell Publishers. pp. 294304

[4] Anderson, J.A. (1996) "The nature of the individual" Ed. J. A. Anderson. Communication Theory: Epistemological Foundation. New York: The Guild Ford P. 1996. pp 77-101

[5] Anthoeny Hall and James Midgley (eds) Development Policies Sociological Perspective, Manchester: Manchester University Press.

[6] Amin, S. (1990) Mal-development: Anatomy of Gobal Failure, London Zed Books.

[7] Amin, S. (1974) Accumulation on World Scale, Monthly Review Press, New York and London.

[8] Baran Paul A. (1957) The Political Economy of Growth, New York: Monthly Review

[9] Brow James (1995) „Political Economy, Agrarian Question and Comparative Method," The Journal of Peasant Studies, Volume 22.No.4 July 1985.pp 561-580.

[10] Dharmasena, P.B. (2004) "Small Tank Herritage and Current Problems", Small Tank Settlements in Sri LankaSymposium, HKAR\&TI, Colombo.

[11] Geertz, C. (1983) Local Knowledge, London Fontana Press.pp 167-234.

[12] Gardner,K. and Lewis, D. (1996) Anthropology, Development and the Post-Modern Development Challenge, London: Pluto Press.

[13] Gunasinghe, N. (1976) Production relations and classes in a Kandyan village (a Sinhalese ${ }^{e c}$ Nava Lanka, Vol. $2 \& 3$.

[14] Hastrup K, (1995) A Passage to Anthropology, London Rutledge

[15] Jayawardena, M.M. (1988) "Pattern of Utilization Resources under Minor Tank in Sri Lanka" MA Tesis University of Peradeniya.

[16] Jayawardena, M. M. (2008) "Divide and rule" Policy and its impacts on economic development in Sri Lanka, International Symposium, University of Kelaniya.

[17] Jayewardene, M.M. (2013). A Theoretical Base for National Defence as a Public Good. 2nd International Economic Research Conference of the Sri Lanka Forum of University Economists (pp. 198 - 204). Peradeniya: Sri Lanka Forum of University Economists (SLFUE).

[18] Kenneth L. Sokoloff, Stanley L. Engerman. (2000) "History Lessons: Institutions, Factor Endowments, and Paths of Development in the New World". The Journal of Economic Perspectives Vol 14 No.3: pp. 217-232

[19] Leach, E. R. (1959), "Hydraulic society in Ceylon," Past and Present, Oxford; also inScience and Civilization in China

[20] Leach, E. R. (1959), "Hydraulic society in Ceylon,” Past and Present, Oxford; also in Science and Civilization in China (1976) by the same author, www.prometheus.org.uk 


\section{International Journal of Science and Research (IJSR) \\ ISSN (Online): 2319-7064}

Index Copernicus Value (2013): 6.14 | Impact Factor (2014): 5.611

[21]Long,Norman.(1988) Sociological Perspectives on Agrarian Development and State Intervention ${ }^{\text {ce }}$

[22] Madduma Bandara, C.M. (1982) Effect of Drought on the Livelihood of Peasant Families In the Dry Zone of Sri Lanka : A Study of the Mahapotana Korale in the North Central Province. Climatological Notes: No.30, University of Tsukuba, Japan.

[23] Madduma Bandara C.M. (1985) Catchment Ecosystems and Village Tank Cascades in the Dry Zone of Sri Lanka: A Time-Tested System of Land and Water Management; in Strategies for River Basin Management (Eds. Lundqvist, J. et.al.) Linkoping, Sweden.

[24] Madduma Bandara, C.M. (1995). Tank cascade systems in Sri Lanka: Some thoughts on their development implications. In Haq, K. A. et.al (Eds.), International Irrigation Management Institute, Colombo, Sri Lanka.

[25] Panabokke, C.R (2000). The small tank cascade systems of the Rajarata: Their setting, distribution patterns, and hydrography.

[26] Rahula W, (1959) What Buddha Taught? Grove Press,New York

[27] Ranis, Gustau, Francis Stewart and Aljendra, Ramiress (2000), Economic Growth and Human Development: World Development, Vol.28, and No.2.

[28] Robertson,A.F. (1984) The People and the State: An anthropology of Planned Development, Cambridge:Cambridge University Press.

[29] Rnaweera Banda RM, (2013) Transnational Culture and Expert Knowledge: Responses from a Rural Community in Sri Lanka,

[30] Sen, Amartya. (997) „Indian Tradition and Western Imaginations ${ }^{\text {ee }}$, Daedalus, Spring, pp. 1-25.

[31] UNCCD, (2005). Promotion of Traditional Knowledge. A Compilation of UNCCD Documents and Reports from 1997 - 2003

[32]Zhang S, Zhu C, Sin JKO, et al (1999) A novel ultrathin elevated channel low-temperature poly-Si TFT, IEEE Electron Device Lett., 20, 569-571.

[33] http://www.sustainablescale.org/attractivesolutions/unde rstandinghumanhappinessandwellbeing.aspx 